\title{
Manobra para palpação abdominal em PACIENTES COM CóCEgAS
}

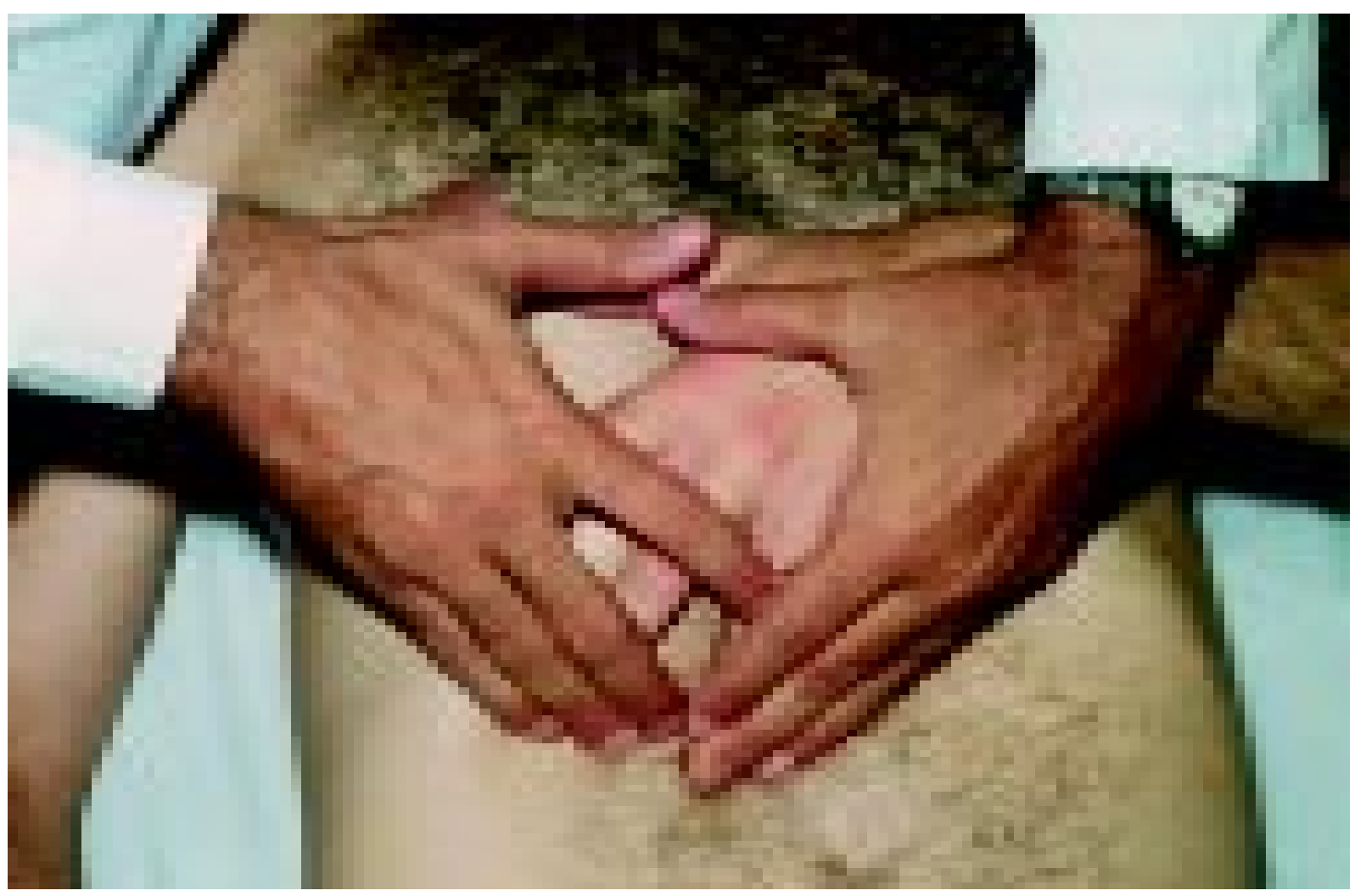

As manobras mais utilizadas consistem em manter o lençol entre a mão do médico e a pele do paciente,

ou desviar a atenção do paciente. Manobra pouco conhecida consiste em utilizar a mão esquerda do paciente sob as mãos do examinador, de tal forma que apenas as pontas dos dedos do examinador fiquem em contato com a pele do paciente.

Dessa maneira, a mão esquerda do paciente produz o estímulo tátil e reduz a resposta à cócegas.

Rute Conceição de Silos

Marilia Haruimi Higuchi dos Santos

InSTITUTO do CORAÇão

Hospital das Clínicas da Faculdade de Medicina da Universidade de São Paulo 